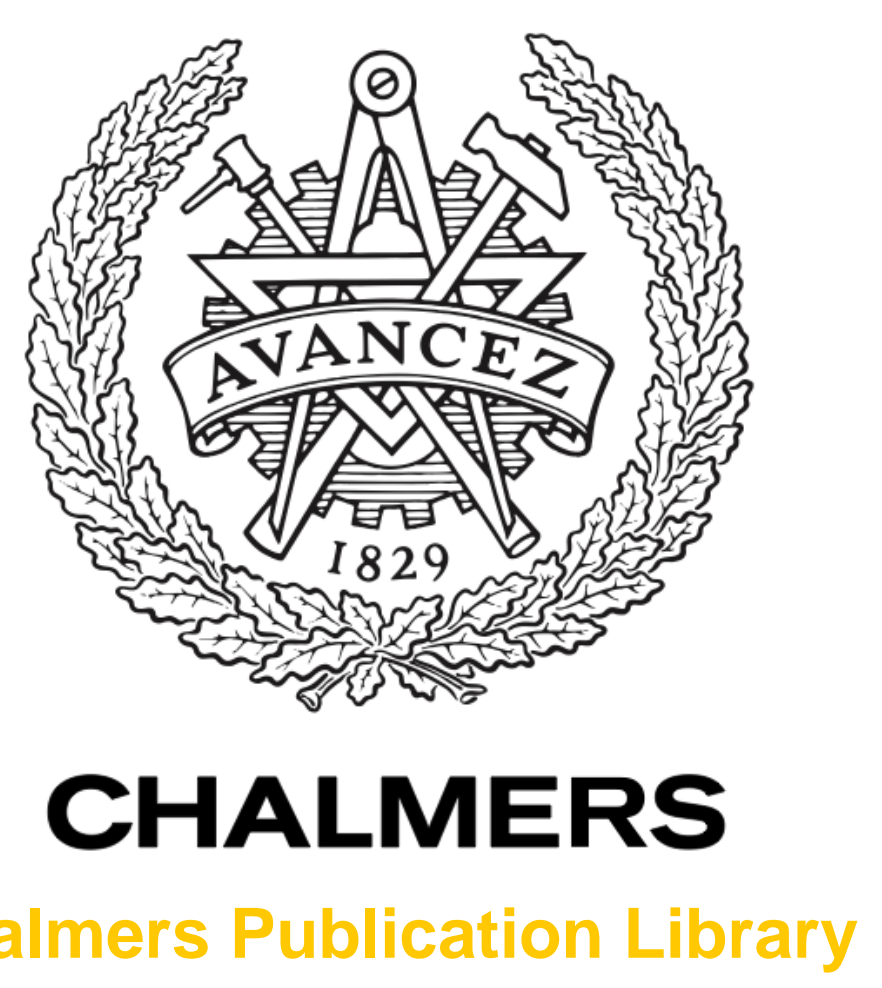

\title{
Combined Cu/Mn Oxides as an Oxygen Carrier in Chemical Looping with Oxygen Uncoupling (CLOU)
}

This document has been downloaded from Chalmers Publication Library $(\mathrm{CPL})$. It is the author's version of a work that was accepted for publication in:

Energy \& Fuels (ISSN: 0887-0624)

Citation for the published paper:

Mohammad Pour, N. ; Leion, H. ; Rydén, M. (2013) "Combined Cu/Mn Oxides as an

Oxygen Carrier in Chemical Looping with Oxygen Uncoupling (CLOU)". Energy \& Fuels, vol. 27(10), pp. 6031-6039.

http://dx.doi.org/10.1021/ef401328u

Downloaded from: http://publications.lib.chalmers.se/publication/185413

Notice: Changes introduced as a result of publishing processes such as copy-editing and formatting may not be reflected in this document. For a definitive version of this work, please refer to the published source. Please note that access to the published version might require a subscription. 


\title{
Combined $\mathrm{Cu} / \mathrm{Mn}$ oxides as oxygen carrier in chemical-looping with oxygen uncoupling (CLOU)
}

\author{
Nasim Mohammad Pour $^{\dagger}$, Henrik Leion ${ }^{\dagger}$, Magnus Rydén ${ }^{\ddagger}$ and Tobias Mattisson ${ }^{\ddagger}$ \\ ${ }^{\dagger}$ Department of Chemical and Biological Engineering, Division of Environmental Inorganic Chemistry, Chalmers University of \\ Technology, S-412 96, Göteborg, Sweden \\ \$Department of Energy and Environment, Division of Energy Technology, Chalmers University of Technology, S-412 96, \\ Göteborg, Sweden
}

\begin{abstract}
This study investigates the $\mathrm{O}_{2}$ uncoupling properties of five different oxygen-carrier particles, consisting of combined oxides of $\mathrm{CuO}$ and $\mathrm{Mn}_{3} \mathrm{O}_{4}$. The oxygen carriers were produced by freeze granulation followed by calcination at $950^{\circ} \mathrm{C}$ for 6 hours. Particles with 5, 10, 20, 31 and 61 wt \% $\mathrm{CuO}$ were examined in both inert (pure $\mathrm{N}_{2}$ ) atmosphere and in the presence of solid fuel (wood char) at $750^{\circ} \mathrm{C}$. At this relatively low temperature during of fluidization with $\mathrm{N}_{2}$, the samples were capable of releasing gas-phase $\mathrm{O}_{2}$ in concentrations up to $1 \%$. During reduction with wood char in $15 \mathrm{~g}$ of oxygen carriers, some materials could release gaseous $\mathrm{O}_{2}$ equal to $1.4 \%$ of their total mass. By measuring the crushing strength and attrition index with a customized jet cup, the mechanical stability of these samples were compared. These measurements showed that, in general, samples with a higher $\mathrm{CuO}$ content were more mechanically stable. Based on XRD analysis of the oxygen carriers, the major phase transitions were $\mathrm{Mn}_{2} \mathrm{O}_{3} \leftrightarrow \mathrm{Mn}_{3} \mathrm{O}_{4}$ and combined spinel $(\mathrm{Cu}, \mathrm{Mn})_{3} \mathrm{O}_{4} \leftrightarrow \mathrm{CuMnO}_{2}$. These transitions both provide a considerable amount of $\mathrm{O}_{2}$. It is concluded that the $\mathrm{Cu}-\mathrm{Mn}-\mathrm{O}$ system has considerable potential to be used as oxygen carrier in chemical-looping applications at lower temperatures, perhaps interesting for biofuel combustion.
\end{abstract}

Keywords: $\mathrm{CO}_{2}$ capture, Chemical looping combustion, Chemical looping with oxygen uncoupling, Oxygen carries, Copper manganese oxides, Biofuels 


\section{- Introduction}

According to IPCC, the global surface temperature of the earth has increased in recent decades ${ }^{1}$. Even slight rise in global temperature (i.e. global warming) could results in catastrophic climate changes. Carbon dioxide is one of the greenhouse gases (GHG) of which a large share of the emission (around 75\%) is known to be anthropogenic ${ }^{2}$. Our dependency on fossil fuels as the primary energy source is the main reason for large anthropogenic $\mathrm{CO}_{2}$ emissions. One way to mitigate $\mathrm{CO}_{2}$ emissions from combustion of fossil fuels is carbon capture and storage (CCS). The purpose of $\mathrm{CCS}$ is to assure sequestration of $\mathrm{CO}_{2}$ and store it away from the atmosphere for a sufficiently long time as to avoid buildup of excessive concentrations in the atmosphere.

Several methods have been proposed and investigated to capture the $\mathrm{CO}_{2}$ produced from fossil fuel combustion. Among the more promising technologies is chemical-looping combustion (CLC). CLC is a process in which a metal oxide (or a combination of metal oxides) is circulating between two reactors. In the fuel reactor, the available oxygen of the metal oxide (usually referred to as oxygen carrier) is consumed by oxidation of injected fuel (reaction 1). Combustion air is passed through the air reactor where the depleted oxygen carrier particles are regenerated (reaction 2).

Fuel reactor: $(2 n+m) \mathrm{Me}_{\mathrm{x}} \mathrm{O}_{\mathrm{y}}+\mathrm{C}_{\mathrm{n}} \mathrm{H}_{2 \mathrm{~m}} \rightarrow(2 \mathrm{n}+\mathrm{m}) \mathrm{Me}_{\mathrm{x}} \mathrm{O}_{\mathrm{y}-1}+\mathrm{mH}_{2} \mathrm{O}+\mathrm{nCO}_{2}$

Air reactor: $2 \mathrm{Me}_{\mathrm{x}} \mathrm{O}_{\mathrm{y}-1}+\mathrm{O}_{2} \leftrightarrow 2 \mathrm{Me}_{\mathrm{x}} \mathrm{O}_{\mathrm{y}}$

Since $\mathrm{O}_{2}$ is transported to the fuel by means of oxygen carrier particles, $\mathrm{CO}_{2}$ and $\mathrm{H}_{2} \mathrm{O}$ are kept separate from flue gas components which originate from combustion air, primarily $\mathrm{N}_{2}$ and excess $\mathrm{O}_{2}$ (see figure 1). Hence, there is no need for costly and energy intensive gas separation using this process in order to obtain $\mathrm{CO}_{2}$ in pure form ${ }^{3}$. To facilitate the use of solid fuels in CLC, Mattisson et.al devised an innovative method known as chemical looping with oxygen uncoupling (CLOU) ${ }^{4}$. CLOU includes three steps; one in the air reactor and two in the fuel reactor. In the first step in the fuel reactor, the oxygen carrier releases gas-phase $\mathrm{O}_{2}$ (reaction 3). In the second step the $\mathrm{O}_{2}$ reacts with combustible gas or char (reactions 4 and 5). The third step is the same as in CLC where reduced oxygen carrier is re-oxidized with oxygen in the air reactor (reaction 6).

In the fuel reactor: 
$\mathrm{Me}_{\mathrm{x}} \mathrm{O}_{\mathrm{y}} \leftrightarrow \mathrm{Me}_{\mathrm{x}} \mathrm{O}_{\mathrm{y}-2}+\mathrm{O}_{2}(\mathrm{~g})$

$\mathrm{C}_{\mathrm{n}} \mathrm{H}_{2 \mathrm{~m}}+\left(\mathrm{n}+\frac{\mathrm{m}}{2}\right) \mathrm{O}_{2}(\mathrm{~g}) \rightarrow \mathrm{nCO}_{2}+\mathrm{mH}_{2} \mathrm{O}$

$\mathrm{C}+\mathrm{O}_{2}(\mathrm{~g}) \rightarrow \mathrm{CO}_{2}$

In the air reactor:

$\mathrm{O}_{2}(\mathrm{~g})+\mathrm{Me}_{\mathrm{x}} \mathrm{O}_{\mathrm{y}-2} \leftrightarrow \mathrm{Me}_{\mathrm{x}} \mathrm{O}_{\mathrm{y}}$

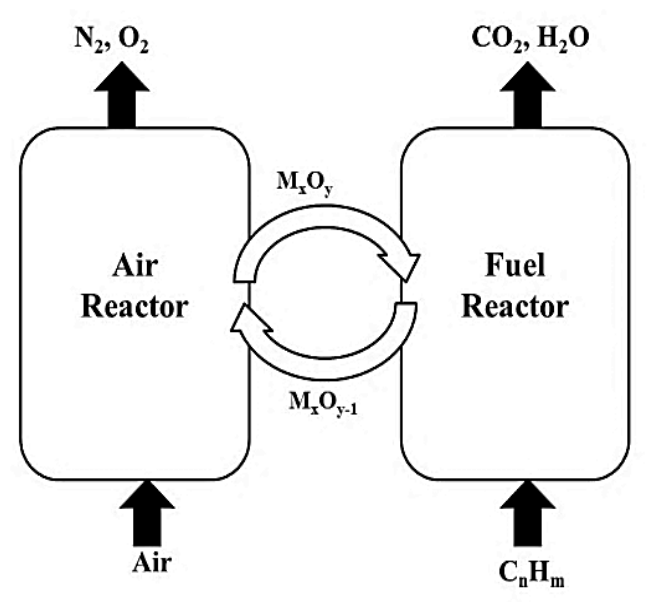

Figure 1. Schematic representation of the chemical-looping combustion process

The net reaction of CLOU (reactions 3-6) is the same as the reaction for normal combustion or for CLC.

Finding suitable oxygen carriers with high reactivity and decent mechanical strength is one of the main concerns of CLC/CLOU, and it is here where a lot of research has been conducted. Different oxides of metals like copper, manganese, nickel and iron have been examined by many CLC researchers ${ }^{5-9}$. The selection of oxygen carriers depends on the fuel and conditions of the system. High reactivity in reduction and oxidation reactions, resistance to fragmentation, attrition and agglomeration, low production cost and environmental impacts and high oxygen transfer capacity are some of the criteria that feasible oxygen carrier materials should fulfill. Of course oxygen carriers for CLOU need to have the special feature of releasing sufficient amount of gas phase oxygen ${ }^{10}$. 
Manganese oxide is a good candidate as oxygen-carrier material due to its low price, comparably high reactivity and low toxicity. Among several phases of Mn-oxides the phase transition between $\mathrm{Mn}_{2} \mathrm{O}_{3}$ to $\mathrm{Mn}_{3} \mathrm{O}_{4}$ is the only one possible for CLOU applications, as can be derived from the thermodynamic properties of manganese oxides ${ }^{4} . \mathrm{Mn}_{2} \mathrm{O}_{3}$ is unstable in air at temperatures higher than $870^{\circ} \mathrm{C}$ and thus decompose irreversibly to $\mathrm{Mn}_{3} \mathrm{O}_{4}$ in a CLC working temperature range $\left(850-950^{\circ} \mathrm{C}\right) \cdot \mathrm{Mn}_{3} \mathrm{O}_{4}$ shows more stability at higher temperatures, so in CLC experiments the phase transition is between $\mathrm{Mn}_{3} \mathrm{O}_{4}$ and $\mathrm{MnO}^{11}$. In the literature there have been a number of studies examining manganese oxide as oxygen carrier for chemical-looping technologies ${ }^{5,12-14}$. Most often the manganese oxide is combined with other materials such as $\mathrm{SiO}_{2}, \mathrm{TiO}_{2}, \mathrm{ZrO}_{2}$, $\mathrm{Ca}(\mathrm{OH})_{2}$ and $\mathrm{Al}_{2} \mathrm{O}_{3}$, which can either act as support or combine with the manganese oxide to form combined oxides. For example, manganese-based oxygen carriers combined with $\mathrm{Fe}_{2} \mathrm{O}_{3}$ have been found to have very interesting properties with respect to CLOU applications ${ }^{15,16}$.

Another strong oxygen carrier candidate is copper oxide. The main challenge of using $\mathrm{CuO}$ as oxygen carrier is that utilization at temperatures above $800^{\circ} \mathrm{C}$ may be problematic with respect to agglomeration and defluidization ${ }^{17}$. Mixing with other metal oxides helps $\mathrm{CuO}$ to improve its physical properties. For instance, oxygen carriers made by $\mathrm{CuO}$ and with $\mathrm{SiO}_{2}, \mathrm{TiO}_{2}$ as support material has shown very good reactivity and mechanical stability ${ }^{6,18-22}$.

Since oxides of $\mathrm{Mn}$ and $\mathrm{Cu}$ both have the ability to release gas phase $\mathrm{O}_{2}$ (CLOU properties) at temperatures $\geq 700^{\circ} \mathrm{C}^{23}$, mixing them to enhance their reactivity and mechanical properties would be of interest ${ }^{4,17,23-25}$. Azad et al have presented an investigation on CLC/CLOU performance of the spinel $\mathrm{Cu}-\mathrm{Mn}-\mathrm{O}$ system ${ }^{24}$. In this study, both $\mathrm{O}_{2}$ release in inert atmosphere and $\mathrm{CH}_{4}$ conversion of one $\mathrm{CuO} / \mathrm{Mn}_{2} \mathrm{O}_{3}$ combination was investigated. From a phase analysis, the authors found a phase transition between spinel $\left(\mathrm{Cu}_{\mathrm{x}} \mathrm{Mn}_{3-\mathrm{x}}\right) \mathrm{O}_{4}$ and $\mathrm{CuMnO}_{2}$ during the reduction, which provided a considerable amount of $\mathrm{O}_{2}$ in a reproducible manner, making the $\mathrm{Cu}$ Mn-O system a possible choice for CLC/CLOU applications.

Because of the limited research conducted with respect to combined oxides of $\mathrm{Cu}$ and $\mathrm{Mn}$, and inlight of the promising results found by Azad et al., the aim of the current study was to investigate the behavior of $\mathrm{Cu}-\mathrm{Mn}$ oxides using different ratios of $\mathrm{Cu} / \mathrm{Mn}$, and to establish the viability of this system with respect to CLOU for solid fuels. 


\section{- Experimental}

\section{Experimental set up}

All the experiments were performed in a straight fluidized-bed reactor with a total length of 820 $\mathrm{mm}$ and a quartz porous plate of $22 \mathrm{~mm}$ in diameter placed $370 \mathrm{~mm}$ from the bottom. Two Pentronic $\mathrm{CrAl} / \mathrm{NiAl}$ thermocouples enclosed in quartz tubes inside the reactor measured the temperature $5 \mathrm{~mm}$ under and $10 \mathrm{~mm}$ above the porous quartz plate. The temperature presented in the paper is the set-point temperature, i.e. the temperature at the beginning of the reduction, as measured by the upper thermocouple.

In order to monitor the $\mathrm{O}_{2}$ release of the different samples at different temperatures, a test protocol with stepwise temperature increase $\left(600,700,750\right.$ and $\left.800^{\circ} \mathrm{C}\right)$ was devised. For experiments with inert $\left(\mathrm{N}_{2}\right)$ gas, a sample of $15 \mathrm{~g}$ oxygen carriers with the size of $125-180 \mu \mathrm{m}$ was placed on the porous plate. The reactor was heated up to the desired temperature in a 900 $\mathrm{mL}_{\mathrm{n}} / \mathrm{min}$ flow of $5 \% \mathrm{O}_{2}$ in nitrogen (oxidation period). When particles were adequately oxidized they were reduced by $600 \mathrm{~mL}_{\mathrm{n}} / \mathrm{min}$ of pure $\mathrm{N}_{2}$ (inert period). The particles were exposed to consecutive cycles of oxidizing and inert periods at these temperatures. Details of the experimental scheme are presented in Table 1.

Table 1. Experimental scheme for reduction with $\mathrm{N}_{2}$. 'Ox' and 'in' denote oxidation and inert periods respectively

\begin{tabular}{lllllll}
\hline $\begin{array}{l}\text { No of } \\
\text { cycles }\end{array}$ & $\begin{array}{l}\text { Reducing } \\
\text { gas }\end{array}$ & $\mathrm{F}_{\text {ox }}(\mathrm{mL} / \mathrm{min})$ & $\mathrm{F}_{\text {in }}(\mathrm{mL} / \mathrm{min})$ & $\mathrm{t}_{\text {in }}(\mathrm{s})$ & $\begin{array}{l}\mathrm{T}_{\mathrm{ox}} \\
\left({ }^{\circ} \mathrm{C}\right)\end{array}$ & $\begin{array}{l}\mathrm{T}_{\text {in }} \\
\left({ }^{\circ} \mathrm{C}\right)\end{array}$ \\
\hline $\mathbf{2}$ & $\mathrm{N}_{2}$ & 900 & 600 & 360 & 600 & 600 \\
$\mathbf{2}$ & $\mathrm{N}_{2}$ & 900 & 600 & 360 & 700 & 700 \\
$\mathbf{2}$ & $\mathrm{N}_{2}$ & 900 & 600 & 360 & 750 & 750 \\
$\mathbf{2}$ & $\mathrm{N}_{2}$ & 900 & 600 & 360 & 800 & 800 \\
\hline
\end{tabular}

For solid fuel experiments, a sample of $15 \mathrm{~g}$ oxygen carrier particles with a size of $125-180 \mu \mathrm{m}$ was heated to $750^{\circ} \mathrm{C}$ in a flow of $1000 \mathrm{~mL}_{\mathrm{n}} / \mathrm{min}$ of a gas mixture consisting $5 \% \mathrm{O}_{2}$ and $95 \% \mathrm{~N}_{2}$. The particles were then alternatingly exposed to this $\mathrm{O}_{2} / \mathrm{N}_{2}$ mixture and reducing periods with solid fuel. The reducing period was carried out using wood char as the solid fuel introduced to the bed of oxygen carrier particles. During reducing periods the reactor was fluidized with 900 
$\mathrm{mL}_{\mathrm{n}} /$ min of pure $\mathrm{N}_{2}$. Throughout the reducing period $300 \mathrm{~mL}_{\mathrm{n}} / \mathrm{min}$ of inert sweep gas, $\mathrm{N}_{2}$, was also introduced to the system at the top of the reactor together with the solid fuel to ensure that the pulverized fuel did not get stuck in the feed line. This sweep gas did not enter the hot reaction zone. The oxidation and the reduction periods were separated by an inert period during which the sample was fluidized with $900 \mathrm{~mL}_{\mathrm{n}} / \mathrm{min}$ of pure $\mathrm{N}_{2}$ for $60 \mathrm{~s}$. This was in order to prevent mixing of oxygen and combustibles. After the solid fuel cycles, the experiments were ended by an extended period during which the particles were exposed to $600 \mathrm{ml} / \mathrm{min}$ flow of $\mathrm{N}_{2}$ at $750^{\circ} \mathrm{C}$. This period lasted until no $\mathrm{O}_{2}$ could be observed in the outgoing gas. The solid fuel used for these tests was wood char, see Table 2.

Table 2. Solid fuel analysis (wt \% dry basis)

\begin{tabular}{ccccccc}
\hline Fuel & Ash & C & H & N & S & O \\
\hline Wood Char & 9.7 & 78.7 & 0.51 & 2.9 & 0.02 & 8.18 \\
\hline
\end{tabular}

All the exhaust gases from the reactor passed through an electric cooler. After $\mathrm{H}_{2} \mathrm{O}$ condensation, the flue gas was led to a gas analyzer (Rosemount NGA-2000), which measures the concentration of $\mathrm{CO}, \mathrm{CO}_{2}, \mathrm{H}_{2}, \mathrm{O}_{2}$ and $\mathrm{CH}_{4}$. From high frequency measurements of the pressure drop over the bed, it was possible to see if the bed was fluidizing. Highly fluctuating pressure drop was interpreted as stable fluidization. In contrast, when the bed is defluidized the measured pressure drop is constant.

\section{Oxygen carriers preparation}

In this work five different $\mathrm{CuO} / \mathrm{Mn}_{3} \mathrm{O}_{4}$ combinations were examined, see Table 3 . The materials were produced using the following method. A water-based slurry of the raw materials (fine chemical powders, $<10 \mu \mathrm{m}$ ) and a small amount of polyacrylic acid as dispersant were prepared by ball milling for $24 \mathrm{~h}$. After milling, some polyvinyl alcohol was added to the slurry as a binder to hold the particles intact during freeze-drying and sintering. Spherical particles were then produced by freeze-granulation, i.e. the slurry is pumped to a spray nozzle, where atomizing air produce drops of the slurry, which are sprayed into liquid nitrogen, where they freeze instantaneously. The frozen water in the resulting particles is then removed by sublimation in a freeze-drier operating at a pressure that corresponds to the vapor pressure over ice at $-10{ }^{\circ} \mathrm{C}$. 
After drying, the particles were divided into different batches, which were sintered at $950^{\circ} \mathrm{C}$ for 6 hours in order to increase their mechanical and chemical integrity. Afterward they were sieved to a size range of $125-180 \mu \mathrm{m}$. A more detailed description of the freeze granulation method can be found elsewhere ${ }^{26}$. The bulk density of the fresh particles in the size range 125-180 $\mu \mathrm{m}$ was determined by measuring the mass and volume of a sample of material. The minimum fluidization velocity $\left(\mathrm{u}_{\mathrm{mf}}\right)$ is calculated based on the relations by Kunii and Levenspiel ${ }^{27}$. The superficial velocity in the reactor system is approximately $0.17 \mathrm{~m} / \mathrm{s}$ for the oxidation period and $0.11 \mathrm{~m} / \mathrm{s}$ for the reducing period with $\mathrm{N}_{2}$ as fluidizing gas.

Table 3. Examined oxygen-carrier materials

\begin{tabular}{ccccccc}
\hline ID & $\begin{array}{c}\mathrm{CuO} / \mathrm{Mn}_{3} \mathrm{O}_{4} \\
\mathrm{wt}^{\circ} \%\end{array}$ & $\begin{array}{c}\overline{d_{p}} \\
(\mu \mathrm{m})\end{array}$ & $\begin{array}{c}\rho_{\text {bulk }} \\
\left(\mathrm{kg} / \mathrm{m}^{3}\right)\end{array}$ & $\begin{array}{c}\mathrm{u}_{\mathrm{mf}} \\
(\mathrm{m} / \mathrm{s})\end{array}$ & $\begin{array}{c}\mathrm{u}_{\mathrm{mf}}^{+} \\
(\mathrm{m} / \mathrm{s})\end{array}$ & $\begin{array}{c}\mathrm{u}_{\mathrm{mf}}^{\dagger} \\
(\mathrm{m} / \mathrm{s})\end{array}$ \\
\hline $\mathbf{C 5 M}$ & $5 / 95$ & 152 & 1409 & 0.007 & 0.007 & 0.007 \\
$\mathbf{C 1 0 M}$ & $10 / 90$ & 152 & 1784 & 0.009 & 0.008 & 0.008 \\
C20M & $20 / 80$ & 152 & 2512 & 0.012 & 0.012 & 0.012 \\
C31M & $31 / 69$ & 152 & 2809 & 0.013 & 0.013 & 0.013 \\
C61M & $61 / 39$ & 152 & 2613 & 0.013 & 0.12 & 0.12 \\
\hline
\end{tabular}

$\$ 5 \%$ Oxygen $(900 \mathrm{ml} / \mathrm{min}$ of Air + Nitrogen $)$ at $750^{\circ} \mathrm{C}$

+ Nitrogen $600 \mathrm{ml} / \mathrm{min}$ at $750^{\circ} \mathrm{C}$

$\dagger 5 \%$ Oxygen $(1000 \mathrm{ml} / \mathrm{min}$ of Air + Nitrogen $)$ at $750^{\circ} \mathrm{C}$

\section{- Data Evaluation}

Oxygen carriers conversion is evaluated by using mass based conversion, $\omega$, which is defined as the actual mass of oxygen carrier, $\mathrm{m}$, divided by the mass of oxygen carrier in the fully oxidized state, $\mathrm{m}_{\mathrm{ox}}$ (equation 7).

$\omega=\frac{m}{m_{o x}}$

In the $\mathrm{N}_{2}$ period $\omega$ is calculated as a time integral of outgoing $\mathrm{O}_{2}$ concentration (equation 8).

$$
\omega_{i}=\omega_{i-1}-\int_{t_{o}}^{t_{1}} \frac{2 \dot{n}_{\text {out }} M_{O}}{m_{o x}} x_{O_{2}} d t
$$


In the solid fuel experiments the mass based conversion during reduction with wood char is described by means of equation 9 .

$$
\begin{aligned}
& \omega_{i}=\omega_{i-1}-\int_{t_{o}}^{t_{1}} \frac{2 \dot{n}_{\text {out }} M_{O}}{m_{o x}}\left(x_{\mathrm{CO}_{2}}+0.5 x_{C O}+x_{\mathrm{O}_{2}}-\left[\left(\frac{O_{2}}{C}\right)_{f u e l} \times\left(x_{\mathrm{CO}_{2}}+x_{C O}+x_{C_{4}}\right)\right]-\right. \\
& \left.\left[\left(\frac{H_{2}}{C}\right)_{\text {fuel }} \times\left(x_{\mathrm{CO}_{2}}+x_{C O}+x_{\mathrm{CH}_{4}}\right)\right]-0.5 x_{\mathrm{H}_{2}}-x_{\mathrm{CH}_{4}}\right) d t
\end{aligned}
$$

Where $\omega_{\mathrm{i}}$ is the mass-based conversion at a given time during a specific period i (oxidation or

reduction), and $\omega_{\mathrm{i}-1}$ is the mass-based conversion at the end of the previous period. $\mathrm{t}_{0}$ and $\mathrm{t}_{1}$ are the times for the start and the end of the period. $\mathrm{x}_{\mathrm{CO} 2}, \mathrm{x}_{\mathrm{CO}}, \mathrm{x}_{\mathrm{H} 2}, \mathrm{x}_{\mathrm{CH} 4}$ and $\mathrm{x}_{\mathrm{O}_{2}}$ represent molar fraction of the gases $\mathrm{CO}_{2}, \mathrm{CO}, \mathrm{H}_{2}, \mathrm{CH}_{4}$ and $\mathrm{O}_{2} . \mathrm{M}_{\mathrm{O}}$ is the molar mass of oxygen and $\dot{n}_{\text {out }}$ represents the molar flow rate of the exhaust gas after condensation of $\mathrm{H}_{2} \mathrm{O} .\left(\mathrm{O}_{2} / \mathrm{C}\right)_{\text {fuel }},\left(\mathrm{H}_{2} / \mathrm{C}\right)_{\text {fuel }}$ are the estimated molar ratios of oxygen and hydrogen over carbon in the fuel.

\section{- Results and Discussion}

\section{CLOU Properties}

To investigate the CLOU properties of the particles, i.e. their ability to release gaseous $\mathrm{O}_{2}$ at relevant temperatures, they were exposed to a reducing atmosphere provided by $\mathrm{N}_{2}$. To the best of our knowledge this is the first experimental study examining $\mathrm{Cu}-\mathrm{Mn}-\mathrm{O}$ with these approximate compositions (see Table 3) as oxygen carrier, so a prudent test protocol was devised to monitor their $\mathrm{O}_{2}$ release at four different temperatures $\left(600,700,750\right.$ and $\left.800^{\circ} \mathrm{C}\right)$. These temperatures could be relevant for biomass combustion, which is one of the intended objectives of studying these particles. As the temperature was raised the $\mathrm{O}_{2}$ release increased as well. This behaviour was seen for all the samples tested in a very similar trend. Figure 2 shows the $\mathrm{O}_{2}$ release of the C5M sample in $\mathrm{N}_{2}$ atmosphere and regeneration in the following oxidizing atmosphere of $5 \% \mathrm{O}_{2}$ as a function of time at the four operating temperatures. At temperatures below $700^{\circ} \mathrm{C}$, there was no sign of gas-phase $\mathrm{O}_{2}$ release and this was the case for all the samples. As the temperature was raised to $750^{\circ} \mathrm{C}$, particles began to release oxygen. For example, after $360 \mathrm{~s} \mathrm{C} 5 \mathrm{M}$ particles had released gaseous $\mathrm{O}_{2}$ constituting $0.2 \mathrm{wt} \%$ of the sample at an $\mathrm{O}_{2}$ partial pressure of $0.006 \mathrm{~atm} . \mathrm{O}_{2}$ release of $\mathrm{C} 5 \mathrm{M}$ particles was highest at $800^{\circ} \mathrm{C}, 0.43 \mathrm{wt} \% \mathrm{O}_{2}$ at $\mathrm{P}_{\mathrm{O} 2}=0.02 \mathrm{~atm}$ at the end of $360 \mathrm{~s}$ 
of the inert period, which should be adequate for CLOU applications. However, at $800^{\circ} \mathrm{C}$, the particles regeneration was problematic, as complete oxidation was not possible for all samples. In fact, C5M particles at $800{ }^{\circ} \mathrm{C}$ released $0.43 \mathrm{wt} \% \mathrm{O}_{2}$ but could regenerated only $0.3 \mathrm{wt} \%$ of it during the following oxidation period. Moreover, at $800^{\circ} \mathrm{C}$ some particles showed a tendency towards agglomeration and defluidization. Therefore, despite higher $\mathrm{O}_{2}$ release at $800^{\circ} \mathrm{C}$ compared to lower temperatures, this may be too high operation temperature for these kinds of materials.

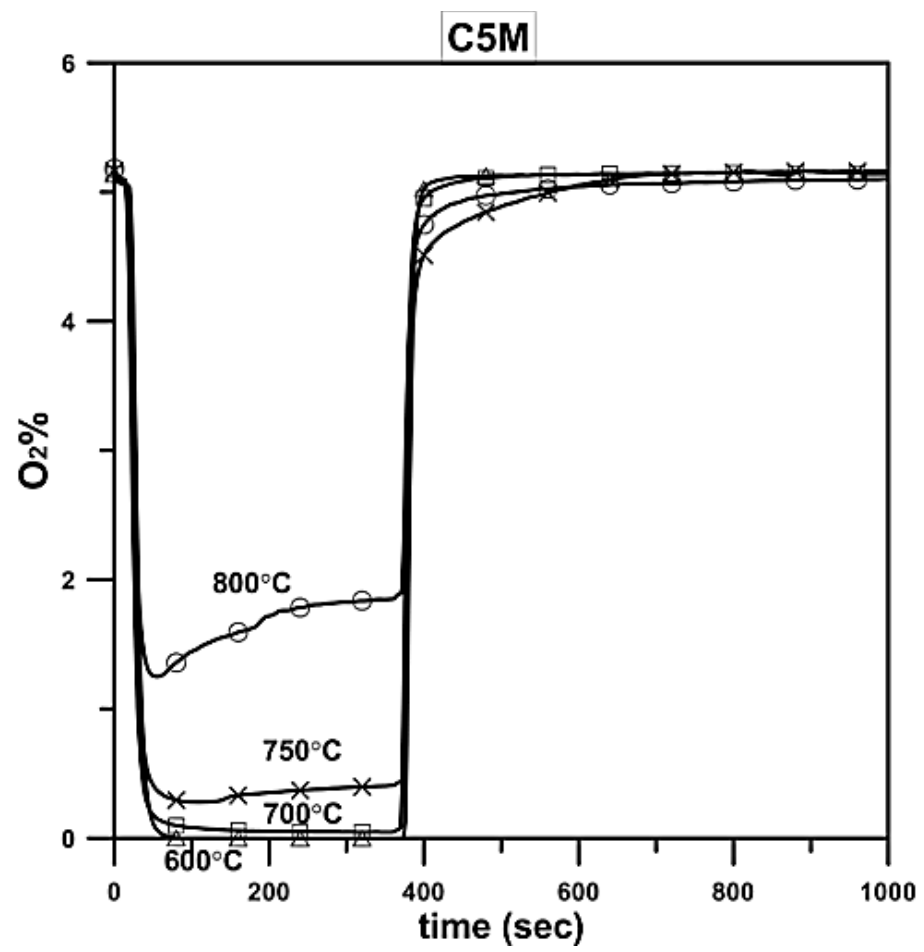

Figure 2. Oxygen release of $\mathrm{C} 5 \mathrm{M}$ particles during reduction with $\mathrm{N}_{2}$ and regeneration by $5 \% \mathrm{O}_{2}$ in the following oxidation period.

Thus, $750^{\circ} \mathrm{C}$ was chosen as the temperature of operation for all the following experiments. According to X-ray powder diffraction, the main phase transition in C5M during oxidation and reduction at $750^{\circ} \mathrm{C}$ is between $\mathrm{Mn}_{2} \mathrm{O}_{3}$ and $\mathrm{Mn}_{3} \mathrm{O}_{4}$. This transition in pure states could provide 3.4 $\mathrm{wt} \% \mathrm{O}_{2}$, but several studies show that re-oxidation of pure $\mathrm{Mn}_{3} \mathrm{O}_{4}$ to $\mathrm{Mn}_{2} \mathrm{O}_{3}$ is a very slow process and nearly irreversible at $750^{\circ} \mathrm{C}{ }^{12,13}$. Seemingly, adding only $5 \% \mathrm{CuO}$ to $\mathrm{Mn}_{3} \mathrm{O}_{4}$ (i.e. C5M particles), facilitated re-oxidizing of $\mathrm{Mn}_{3} \mathrm{O}_{4}$ to $\mathrm{Mn}_{2} \mathrm{O}_{3}$ greatly. As it can readily be seen in Figure 2, after having been reduced for $360 \mathrm{~s}$ in $\mathrm{N}_{2}$ atmosphere C5M particles were capable of retaining all the $\mathrm{O}_{2}$ they had previously released in less than $200 \mathrm{~s}$, when being exposed to $5 \% \mathrm{O}_{2}$. 
Figure 3 shows the $\mathrm{O}_{2}$ release as a function of time at $750^{\circ} \mathrm{C}$, for the different material compositions. As shown, at the end of $360 \mathrm{~s}$ of $\mathrm{N}_{2}$, all the samples released $\mathrm{O}_{2}$ at concentration more than $0.5 \%$. From the figure, it is clear that $\mathrm{C} 5 \mathrm{M}$ has a peculiar $\mathrm{O}_{2}$ release behaviour. During the first $160 \mathrm{~s}$ it is around $0.3 \% \mathrm{O}_{2}$, after which it began to release more $\mathrm{O}_{2}$ at an accelerating rate. At the end of the $360 \mathrm{~s}$ the outlet concentration is almost $0.6 \%$. Seemingly there is a short delay in its activation. Other samples had stable or decreasing reactivity with time.

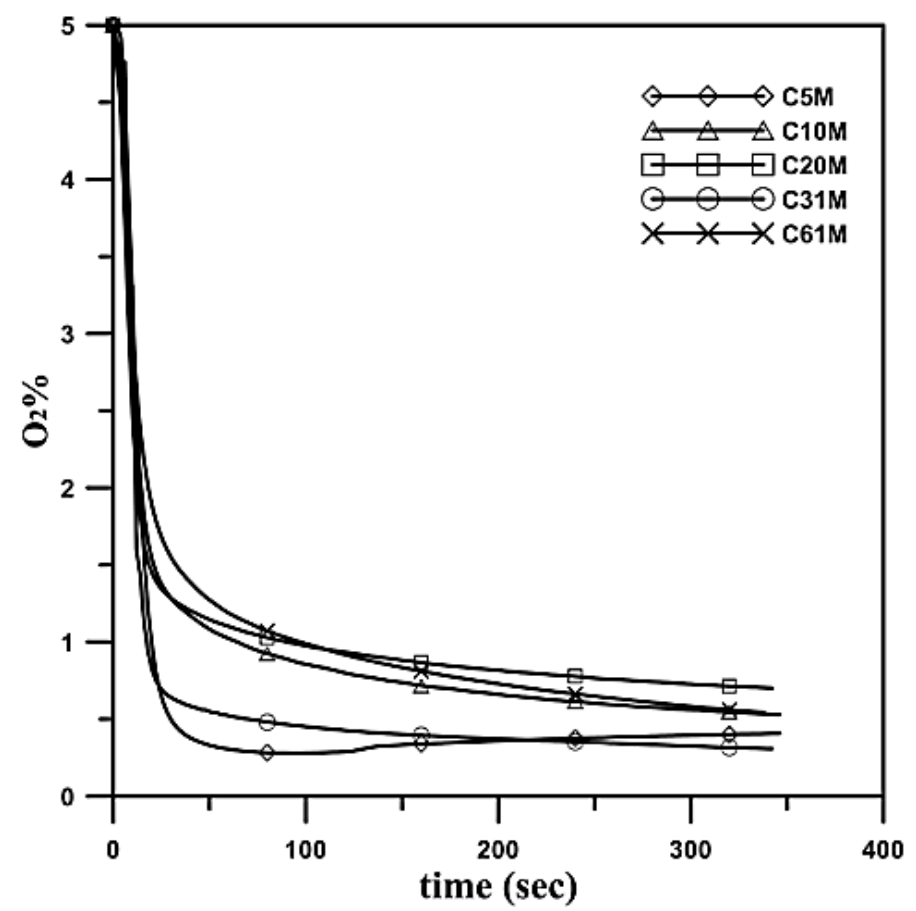

Figure 3. Oxygen release during reduction with $\mathrm{N}_{2}$ at $750^{\circ} \mathrm{C}$

\section{Solid fuel conversion}

Although the uncoupling experiments with $\mathrm{N}_{2}$ established that these materials have CLOU properties, an actively reducing atmosphere is required to reveal the true rate at which oxygen can be released from the particles. Hence each sample was examined with solid fuel experiments, in which $15 \mathrm{~g}$ of oxygen carrier were reduced by wood char at $750^{\circ} \mathrm{C}$.

In order to be able to remove all the active $\mathrm{O}_{2}$ from the oxygen carrier particles, injection of sufficient amount of solid fuel needs to be ensured. To this end, the amount of the fuel added to the reactor was gradually increased in several consecutive cycles, from $0.1 \mathrm{~g}$ to start with, up to the amount for which during the subsequent oxidation a clear $\mathrm{CO}_{2}$ peak from the unburnt char 
could be observed ( $0.5 \mathrm{~g}$ fuel for C5M and C10M, $0.3 \mathrm{~g}$ fuel for C20M and C31M and $0.7 \mathrm{~g}$ fuel for $\mathrm{C} 61 \mathrm{M}$ particles). Observing $\mathrm{CO}_{2}$ in the flue gas during the oxidation ensures that the oxygen carrier particles have in fact received an excess of solid fuel during the reduction period. Depending on $\mathrm{O}_{2}$ release ability of the samples and to ensure the reproducibility of the experiments, each fuel cycle was repeated at least three times. Hence, each sample experienced 36 consecutive solid fuel cycles. At constant conditions the cycle number was seen to have no considerable effect on the performance of particles.

Volume fraction of the product gases during a whole fuel cycle consisting of an oxidation period followed by a fuel and oxidation period for C5M particles is illustrated in figure 4 . The used wood char contained some volatiles as can be seen by the $\mathrm{CO}_{2}$ peak and the release of $\mathrm{CH}_{4}$ and $\mathrm{CO}$ initially. Some of the released volatiles react with the oxygen carrier and $\mathrm{CO}_{2}$ increases rapidly. The $\mathrm{CO}_{2}$ peak in the oxidation period after the fuel period is due to the reaction of the remained unreacted char and the incoming oxygen.

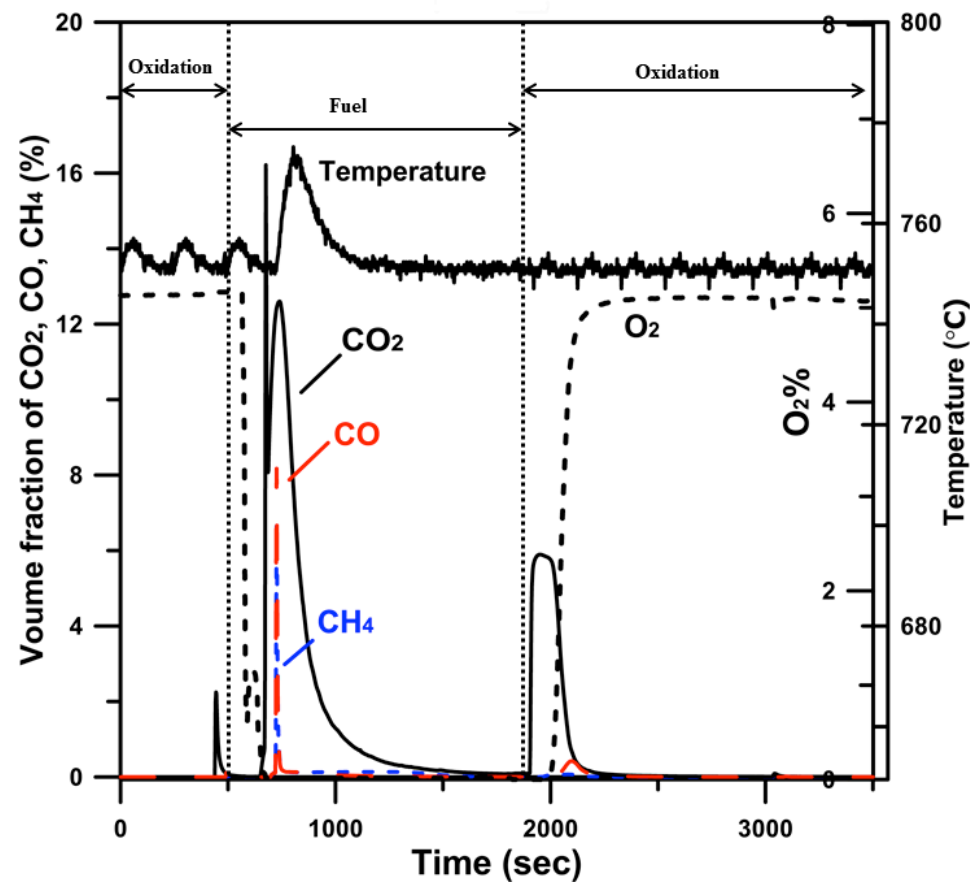

Figure 4. Concentrations for the reduction in a fuel cycle with $0.5 \mathrm{~g}$ of wood char in $15 \mathrm{~g}$ of $\mathrm{C} 5 \mathrm{M}$ particles

The outlet gas concentrations as a function of time in a $300 \mathrm{~s}$ interval immediately after the fuel introduction for the $\mathrm{C} 5 \mathrm{M}, \mathrm{C} 31 \mathrm{M}$ and $\mathrm{C} 61 \mathrm{M}$ particles are illustrated in figure 5 . When the fuel is introduced to the reactor at $750^{\circ} \mathrm{C}$ the volatiles are released in a few seconds. In the initial stages 
the released volatiles provide a condition under which oxygen carriers are stimulated to release more $\mathrm{O}_{2}$, either by lowering the oxygen concentration in the reactor (indirect reaction) or by consuming oxygen more rapidly than it can be released (direct reaction), resulting in a high rate of reaction.

When fuel devolatilization is completed, the remaining char is only consumed by reaction with the oxygen released from the oxygen carrier. Since the fluidizing gas is nitrogen, there is no or very little gasification taking place. Thus, the $\mathrm{CO}_{2}$ concentration out of the reactor is a measure of the oxygen release rate from the particles.

After $20 \mathrm{~s}$ the devolatilization was over and in case of $\mathrm{C} 5 \mathrm{M}$ and $\mathrm{C} 61 \mathrm{M}$ particles $\mathrm{CO}_{2}$ started an increasing trend again, which is likely due to the temperature increase in the bed, reaching a maximum of $775^{\circ} \mathrm{C}$. The temperature increase is because the overall reaction when $\mathrm{O}_{2}$ is released from the particles and reacts with char is exothermic. This temperature increase could establish a positive feedback mechanism, in which the temperature increase promote the release of $\mathrm{O}_{2}$ to the gas phase, and hence result in higher rate of char conversion which consequently leads to increased temperature.

The fuel periods last until no $\mathrm{CO}_{2}$ was detected in the outlet gases, meaning that all available oxygen for the CLOU process has been utilized for combustion. As seen, $\mathrm{CO}_{2}$ concentration and temperature increase during reduction of $\mathrm{C} 31 \mathrm{M}$ particles is significantly lower than the $\mathrm{C} 5 \mathrm{M}$ and C61M samples. This could to some extent be due to lack of positive feedback via the mechanism explained above. Basically, the low reactivity in the beginning of the reduction period does not result in increased reactor temperature and improved conditions for $\mathrm{O}_{2}$ release. 

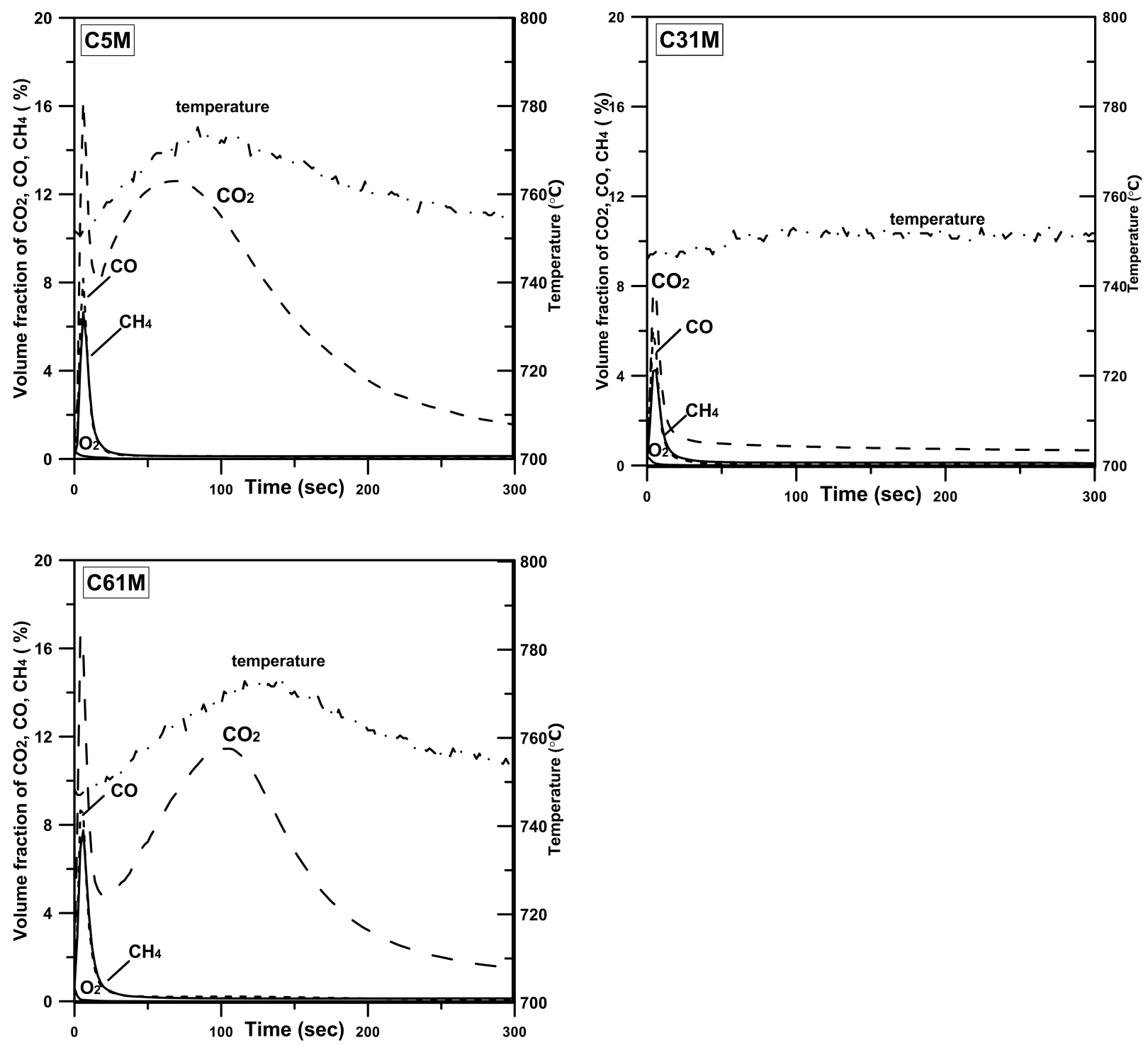

Figure 5. Concentrations for the reduction in a fuel period of $0.5 \mathrm{~g}$ wood char in $15 \mathrm{~g}$ of C5M, $0.3 \mathrm{~g}$ wood char in 15 $\mathrm{g}$ of $\mathrm{C} 31 \mathrm{M}$ and $0.7 \mathrm{~g}$ wood char in $15 \mathrm{~g}$ C61M particles, during the initial $300 \mathrm{~s}$ after fuel injection

The $\mathrm{CO}_{2}$ concentration as a function of oxygen carrier mass conversion during the whole fuel period for all the samples is presented in figure 6. As can be seen, the $\mathrm{C} 5 \mathrm{M}, \mathrm{C} 10 \mathrm{M}$ and $\mathrm{C} 61 \mathrm{M}$ samples with $\Delta \omega$ equal to $1.4 \%$ had similar mass and $\mathrm{CO}_{2}$ conversion during the fuel periods. On the other hand, $20 \mathrm{M}$ and $\mathrm{C} 31 \mathrm{M}$ with $\mathrm{O}_{2}$ release $\approx 1 \mathrm{wt} \%$ showed less reactivity. 


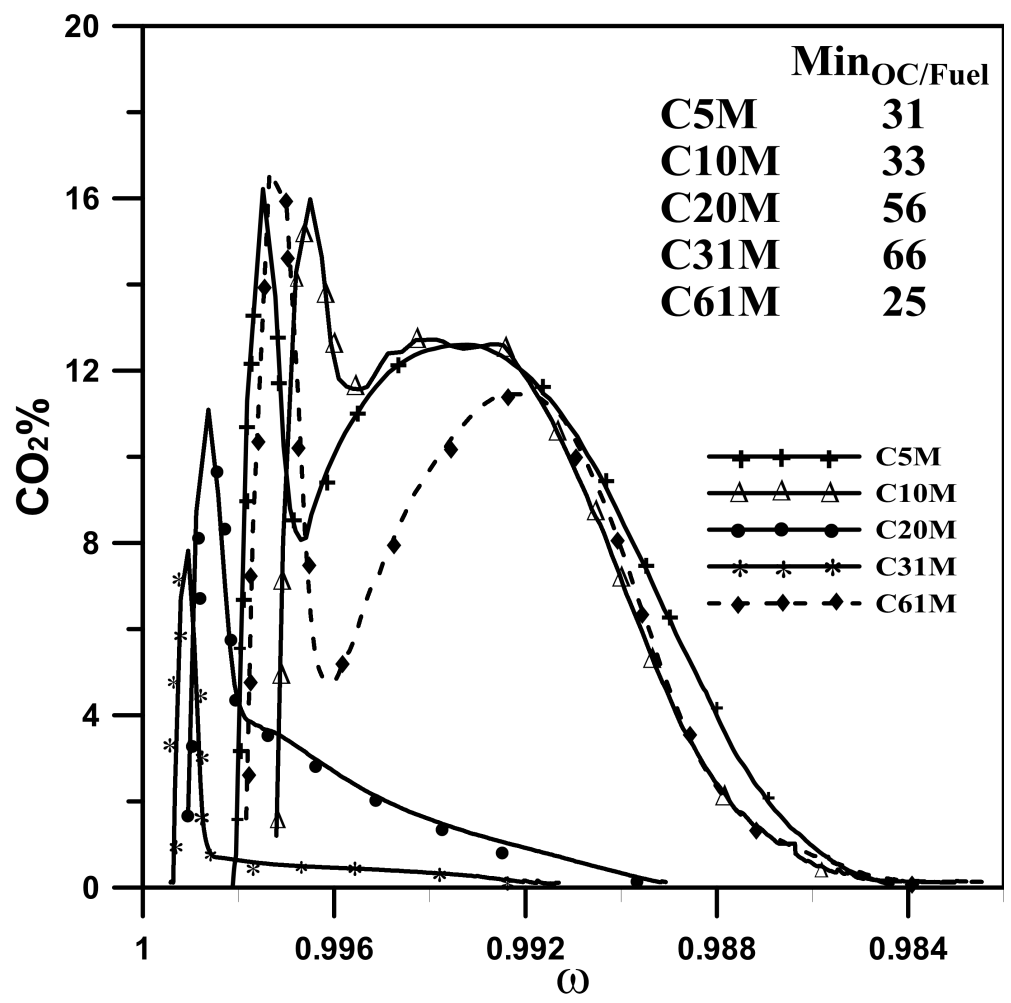

Figure 6. $\mathrm{CO}_{2}$ volume fraction as a function of oxygen carrier mass-based conversion for the reduction with wood char at $750{ }^{\circ} \mathrm{C}$, The fluidizing is $900 \mathrm{~mL}_{\mathrm{n}} / \mathrm{min}$ of pure $\mathrm{N}_{2}$

In figure 6 , value of the minimum weight ratio of oxygen carrier-to-fuel required to achieve complete combustion of char, Min OC/Fuel, is reported for each material. The amount of the fuel burnt by the released $\mathrm{O}_{2}$ from the oxygen carrier particles was calculated by subtracting the weight of the unreacted char from the weight of injected fuel. The amount of unreacted char could be calculated from the total $\mathrm{CO}_{2}$ released during the oxidation period after each reduction period.

As mentioned above, solid fuel experiments provide a method of obtaining the oxygen capacity and the maximum rate of oxygen release, something which is more difficult using only $\mathrm{N}_{2}$, where the reaction rate may be limited by thermodynamic constraints, see Figure 3. This can be seen in figure 7 , which compares the average rate of mass-based conversion of the samples at $750^{\circ} \mathrm{C}$ during fluidization with $\mathrm{N}_{2}$, with and without wood char addition. In figure 7, the graph illustrating reaction rate during reduction by pure $\mathrm{N}_{2}$ refers to the extended period after the solid fuel experiments during which the particles were exposed to a $600 \mathrm{ml} / \mathrm{min}$ flow of $\mathrm{N}_{2}$. This period lasted until no $\mathrm{O}_{2}$ could be observed in the outgoing gas, at which point it was assumed that the 
particles had been reduced as much as it is possible at these operating conditions. Here, the rate is derived from the total amount of oxygen released during the whole reduction period for both cases.

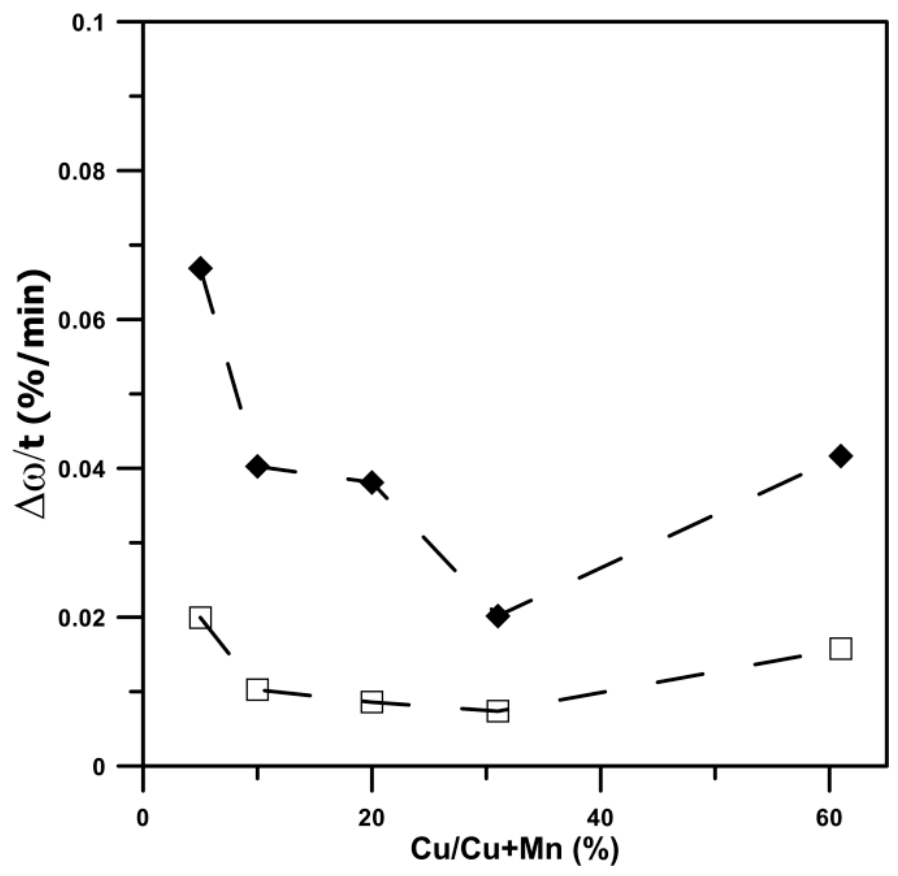

Figure 7. Oxygen carrier mass-based conversion rate as a function of $\mathrm{Cu} / \mathrm{Cu}+\mathrm{Mn}(\mathrm{wt} \%)$ of $15 \mathrm{~g}$ of oxygen carriers at $750^{\circ} \mathrm{C}$. Reduction with wood char $(\diamond)$ and $600 \mathrm{ml}_{\mathrm{n}} / \mathrm{min}$ of pure $\mathrm{N}_{2}(\square)$

As can be seen in Figure 7 there is a substantial difference between the two cases. Most of samples are reduced almost three times as fast when wood char is present, compared to the $\mathrm{N}_{2}$ periods. Although the reactivity variance of the samples in solid fuel experiment is larger, nevertheless both graphs show the same trend. Under both conditions C5M particles produce $\mathrm{O}_{2}$ at a higher rate than others. As the $\mathrm{CuO}$ content increase from 5 to $31 \mathrm{wt} \%$ the reactivity follows a decreasing trend (from 0.066 to $0.02 \% / \mathrm{min}$ ). As the $\mathrm{CuO}$ was doubled from 31 to $61 \mathrm{wt} \%$, the $\mathrm{O}_{2}$ release doubled as well. It should be mentioned that in Figure 7, the actual conversion level where the rates are obtained varies and depends upon the time period under reduction (char or inert nitrogen), but the figure illustrates the higher rates obtained once char is introduced to the bed of particles. 


\section{- Oxygen carrier characterisation}

The analysis of the phase composition of the oxygen carrier particles was performed on a Siemens D5000 powder X-ray diffractometer $(\mathrm{Cu} \mathrm{Ka1,} \mathrm{k}=1.54056 \AA)$. X-ray spectra of samples oxidized in $5 \% \mathrm{O}_{2}$ and fully reduced by pure $\mathrm{N}_{2}$ at $750^{\circ} \mathrm{C}$ are presented in figure 8 .
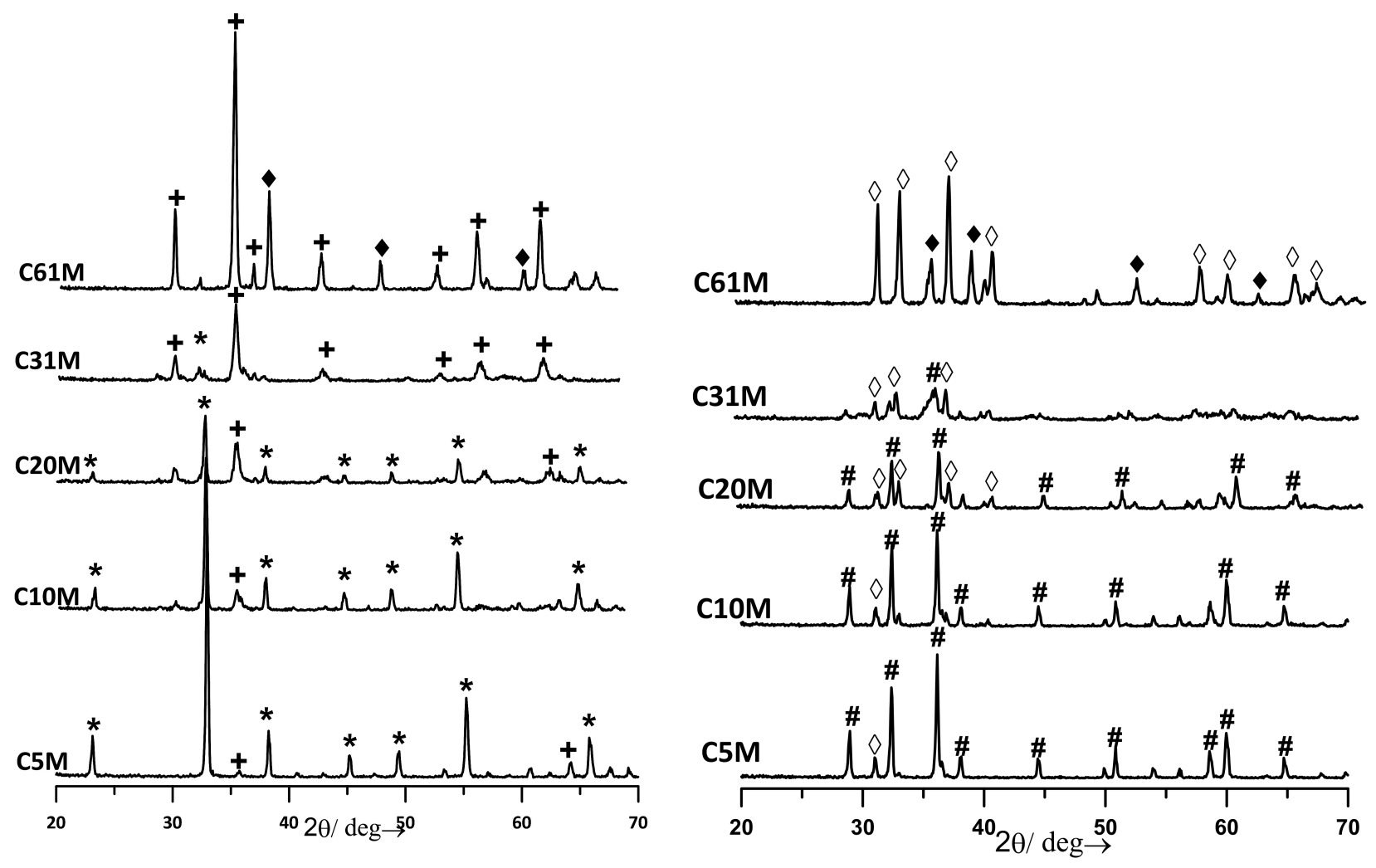

Figure 8. XRD powder patterns for materials belonging to the $\mathrm{Cu}-\mathrm{Mn}$ system, oxidized in $5 \% \mathrm{O}_{2}(\mathrm{left})$ and reduced in $\mathrm{N}_{2}$ (right) at $750^{\circ} \mathrm{C} . \mathrm{Mn}_{2} \mathrm{O}_{3}(*),(\mathrm{Cu}, \mathrm{Mn})_{3} \mathrm{O}_{4}(+), \mathrm{CuO}(\diamond), \mathrm{Mn}_{3} \mathrm{O}_{4}(\#), \mathrm{CuMnO}_{2}(\diamond)$

As can be seen in Figure 8, for the oxidized samples the dominant phase in samples with $\mathrm{CuO}$ wt $\% \leq 10 \%$ is bixbyite $\left(\mathrm{Mn}_{2} \mathrm{O}_{3}\right)$. As the $\mathrm{CuO}$ content increases peaks of spinel $(\mathrm{Cu}, \mathrm{Mn})_{3} \mathrm{O}_{4}$ emerge and those of $\mathrm{Mn}_{2} \mathrm{O}_{3}$ shrink. Looking at the graphs of $\mathrm{C} 5 \mathrm{M}$ and $\mathrm{C} 61 \mathrm{M}$ as the two ends of the range, this transition is vividly recognizable. After several consecutive fuel cycles, oxygen carriers were exposed to $600 \mathrm{~mL}_{\mathrm{n}} / \mathrm{min}$ of pure $\mathrm{N}_{2}$ and reduced completely. The phases of reduced particles were pretty much what were expected. Bixbyite $\left(\mathrm{Mn}_{2} \mathrm{O}_{3}\right)$ was reduced to hausmannite $\left(\mathrm{Mn}_{3} \mathrm{O}_{4}\right)$ and spinel $(\mathrm{Cu}, \mathrm{Mn})_{3} \mathrm{O}_{4}$ converted to $\mathrm{CuMnO}_{2}$. Seemingly in $\mathrm{C} 61 \mathrm{M}$ there is an excess of 
tenorite $(\mathrm{CuO})$ that couldn't be reduced completely at $750^{\circ} \mathrm{C}$. These phase transitions are in conformity with the results reported by Azad et.al ${ }^{24}$.

The shape and morphology of the particles, oxidized at $750^{\circ} \mathrm{C}$, were observed using a FEI, Quanta 200 Environmental Scanning Electron Microscope FEG. The Scanning Electron Microscopy, SEM, image of the samples looked very similar hence only those of C51M and $\mathrm{C61 \textrm {M }}$ are illustrated in Figure 9. One can see that the particles have a spherical structure and their surface is porous.
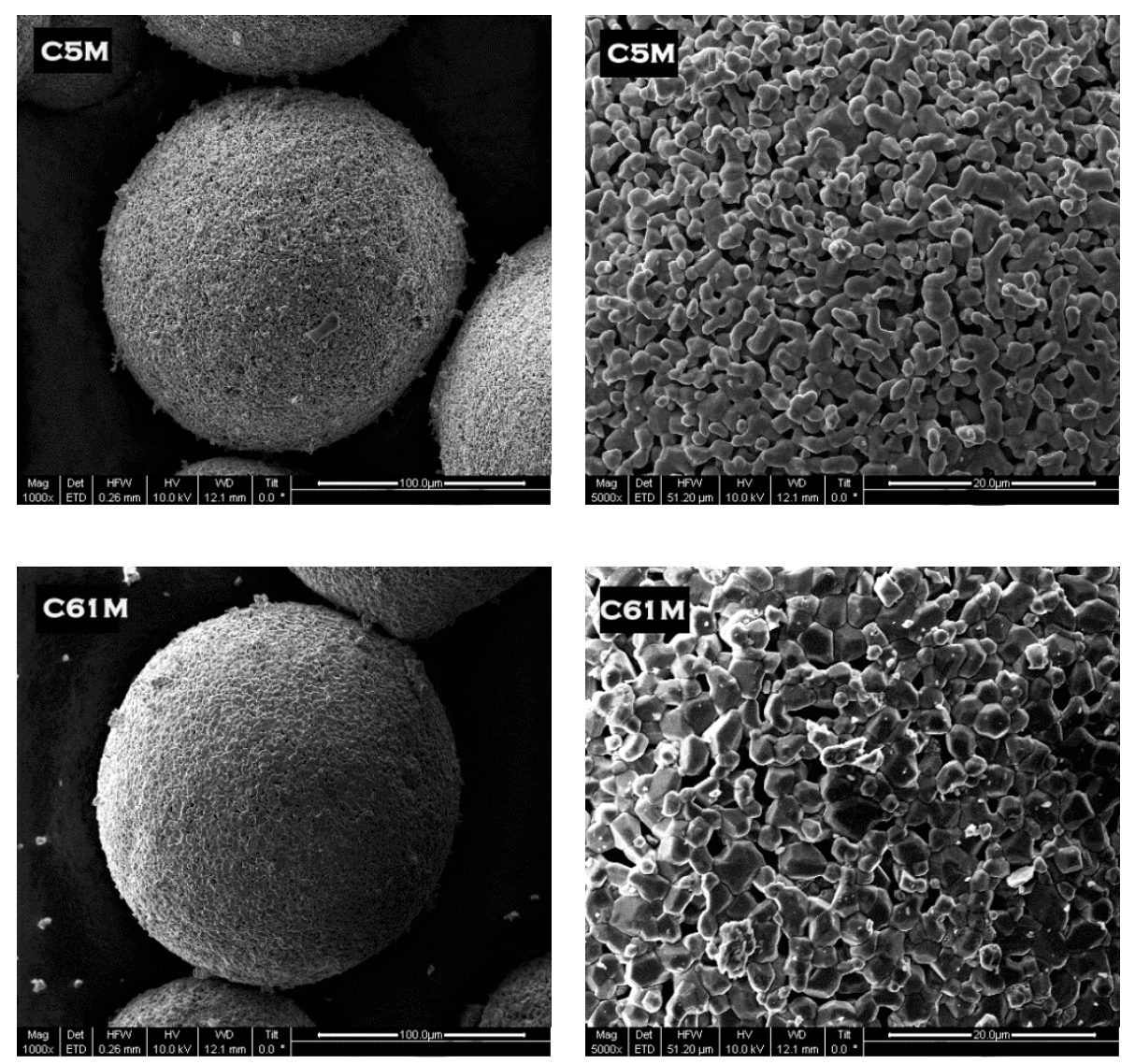

Figure 9. SEM images of $\mathrm{C} 5 \mathrm{M}$ and $\mathrm{C} 61 \mathrm{M}$ particles oxidized at $750^{\circ} \mathrm{C}$. The images are $1000 \mathrm{x}$ magnified at $100 \mu \mathrm{m}$ range (left) and 5000x magnified at $20 \mu \mathrm{m}$ range (left).

The crushing strength of the different materials, i.e. the force needed to fracture the particles, was determined using a Shimpo FGN-5 crushing strength apparatus. The reported values are average for 30 particles in the range size of $180-250 \mu \mathrm{m}$, see figure 10 . 
Another important property of particles used as oxygen carriers is their resistance to mechanical attrition. In a fluidized bed, gas typically enters the bed via nozzles and often at very high velocities. Due to these gas jets weak particles can be subjected to fragmentation and by colliding with each other and with the reactor walls they may also be subjected to abrasion. Attrition resistance of selected samples was measured in a customized attrition test apparatus. The attrition test rig was based on the jet cup method, as described by Cocco et al ${ }^{28}$. A detailed description of the customized jet cup apparatus and method used can be found elsewhere ${ }^{29}$. After having been tested in several cycles of gaseous and solid fuel experiments, $5 \mathrm{~g}$ samples of each material composition were examined in attrition test rig for $1 \mathrm{~h}$. Reported attrition index basically means the mass $\%$ of the sample which was elutriated as fines from the test rig after $1 \mathrm{~h}$. Attrition and crushing strength tests results are presented in Figure 10.

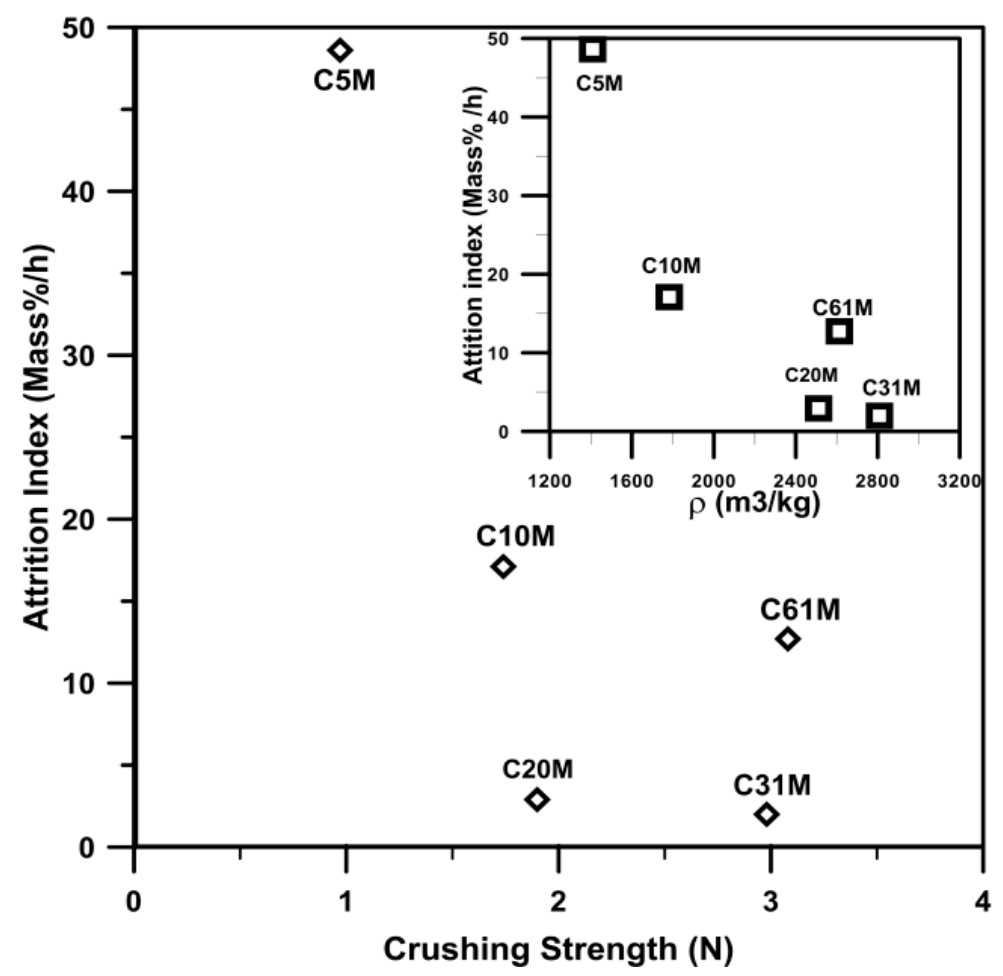

Figure 10. Attrition index of the used samples as a function of crushing strength and density

As can be seen in figure 10, increasing $\mathrm{CuO}$ content improves the crushing strength of the samples. Thus, $\mathrm{C} 61 \mathrm{M}$ with $61 \mathrm{wt} \% \mathrm{CuO}$ has three times higher crushing strength than $\mathrm{C} 5 \mathrm{M}$ with $5 \mathrm{wt} \% \mathrm{CuO}$. Particles of $\mathrm{C} 20 \mathrm{M}, \mathrm{C} 31 \mathrm{M}$ and $\mathrm{C} 61 \mathrm{M}$ with crushing strength above $2 \mathrm{~N}$ could be considered as sufficiently hard, according to the study by Rydén et al ${ }^{29}$. Although C61M with 
highest $\mathrm{CuO} \mathrm{wt} \%$ has higher attrition index than $\mathrm{C} 20 \mathrm{M}$ and $\mathrm{C} 31 \mathrm{M}$ but it could be said that in general having higher $\mathrm{wt} \% \mathrm{CuO}$ enhances the attrition resistance of the particles as well.

\section{- Conclusion}

In this work the $\mathrm{CLOU}$ properties of five combined $\mathrm{Cu} / \mathrm{Mn}$ oxygen carrier-particles were investigated. Oxygen carriers with 5, 10, 20,31 and $61 \mathrm{wt} \% \mathrm{CuO}$ were first exposed to pure $\mathrm{N}_{2}$ at different temperatures in the range of $600^{\circ} \mathrm{C}$ to $800^{\circ} \mathrm{C}$. A temperature of $750^{\circ} \mathrm{C}$ was chosen as the most suitable temperature of operation for further experiments. At this relatively low temperature during reduction by $\mathrm{N}_{2}$, the samples still were capable of releasing gas-phase $\mathrm{O}_{2}$, at concentrations up to $1 \%$. As revealed by XRD analysis of the oxygen carriers oxidized and reduced at $750^{\circ} \mathrm{C}$, the major phase transition was $\mathrm{Mn}_{2} \mathrm{O}_{3} \leftrightarrow \mathrm{Mn}_{3} \mathrm{O}_{4}$ and spinel $(\mathrm{Cu}, \mathrm{Mn})_{3} \mathrm{O}_{4} \leftrightarrow \mathrm{CuMnO}_{2}$, both of which can release considerable amount of gas phase oxygen. This was confirmed by conducting solid fuel experiments at $750^{\circ} \mathrm{C}$ with $15 \mathrm{~g}$ of oxygen carriers and wood char as the fuel. During these experiments the samples were fluidized with $\mathrm{N}_{2}$ in order to inhibit gasification of the wood char. Samples with 5, 10 and $61 \mathrm{wt} \% \mathrm{CuO}$ (C5M, C10M and $\mathrm{C} 61 \mathrm{M})$ were found to release up to $1.4 \mathrm{wt} \% \mathrm{O}_{2}$ at these conditions. During reduction in presence of wood char, the oxygen carriers released $\mathrm{O}_{2}$ at least three times faster compared to when fluidized with pure $\mathrm{N}_{2}$. Generally, the oxygen carriers with very high or very low $\mathrm{CuO}$ content (C5M, C10M and $\mathrm{C} 61 \mathrm{M}$ ) showed significantly better reactivity than those with average $\mathrm{CuO}$ content (C20M and $\mathrm{C} 31 \mathrm{M})$. No sign of defluidization, agglomeration or significant attrition was observed for the experiments conducted at $750^{\circ} \mathrm{C} . \mathrm{C} 5 \mathrm{M}(5 \mathrm{wt} \% \mathrm{CuO})$ was found to have the best reactivity, very low crushing strength $(1 \mathrm{~N})$ and poor attrition resistance (attrition index 47 mass $\% / \mathrm{h})$. On the other hand, $\mathrm{C} 61 \mathrm{M}(61 \mathrm{wt} \% \mathrm{CuO})$ showed both good reactivity and mechanical stability. Comparing crushing strength and attrition index measurements, it was observed that in general samples with higher $\mathrm{CuO} \mathrm{wt} \%$ appeared to be more mechanically stable. The results obtained by this work clearly show that $\mathrm{Cu}-\mathrm{Mn}-\mathrm{O}$ system have great potential to be used as oxygen carrier in CLOU, perhaps most significant for fuels where oxidation at low temperature could be an advantage such as biofuels or waste. 


\section{- Acknowledgment}

This work was financed by Swedish energy agency (Energimyndigheten), Göteborg Energi and Stiftelsen för forskning och utveckling.

\section{- References}

(1) Bates, B.; Kundzewicz, Z. W.; Wu, S; Palutikof, J. Climate Change and Water,iPCC technical Paper Vi. Intergovernmental Panel on Climate Change. IPCC Secretariat, 2008. Geneva: p. 210.

(2) Archer, D. Fate of fossil fuel CO2 in geologic time. Journal of Geophysical Research-Oceans, 2005. 110(C9).

(3) Lyngfelt, A.; Leckner, B.; Mattisson, T. A fluidized-bed combustion process with inherent $\mathrm{CO}_{2}$ separation; application of chemical-looping combustion. Chemical Engineering Science, 2001. 56(10): p. 3101-3113.

(4) Mattisson, T.; Lyngfelt, A.; Leion, H. Chemical-looping with oxygen uncoupling for combustion of solid fuels. International Journal of Greenhouse Gas Control. 2009. 3(1): p. 11-19.

(5) de Diego, L, F.; Adanez, J.; Garcia-Labiano, F.; Gayan, P.; Abad, A.; Palacios, J, M. Selection of Oxygen Carriers for Chemical-Looping Combustion. Energy \& Fuels, 18 (2004), 371-77.

(6) Mattisson, T.; Cho, P.; Lyngfelt, A. Comparison of Iron-, Nickel-, Copper- and Manganese-Based Oxygen Carriers for Chemical-Looping Combustion. Fuel, 83 (2004), 1215-25.

(7) Siriwardane, R.; Tian, H,J.; Richards, G.; Simonyi, T.; Poston, J. Chemical-Looping Combustion of Coal with Metal Oxide Oxygen Carriers. Energy \& Fuels, 2009. 23(8): p. 3885-3892.

(8) Lyngfelt, A. Oxygen Carriers for Chemical Looping Combustion-4000 H of Operational Experience. Oil \& Gas Science and Technology-Revue D Ifp Energies Nouvelles, 66 (2011), 161-72.

(9) Dueso, C.; Ortiz, M.; Abad, A.; Garcia-Labiano, F.; de Diego, L, F.; Gayan, P.; Adanez, J. Reduction and oxidation kinetics of nickel-based oxygen-carriers for chemical-looping combustion and chemical-looping reforming. Chemical Engineering Journal, 2012. 188: p. 142-154.

(10) Mattisson, T. Materials for Chemical-Looping with Oxygen Uncoupling. ISRN Chemical Engineering, 2013 (2013).

(11) Stobbe, E,R .; de Boer, B,A.; Geus, J,W. The reduction and oxidation behaviour of manganese oxides. Catalysis Today, 1999. 47: p. 161-167.

(12) Zafar, Q.; Abad, A.; Mattisson, T.; Gevert, B.; Strand, M. Reduction and oxidation kinetics of $\mathrm{Mn}_{3} \mathrm{O}_{4} / \mathrm{Mg}-\mathrm{ZrO}_{2}$ oxygen carrier particles for chemical-looping combustion. Chemical Engineering Science, 2007. 62(23): p. 6556-6567. 
(13) Johansson, M.; Mattisson, T.; Lyngfelt, A. Investigation of Mn3O4 with stabilized $\mathrm{ZrO} 2$ for chemical-looping combustion. Chemical Engineering Research \& Design, 2006. 84(A9): p. 807-818.

(14) Rydén, M.; Lyngfelt, A.; Mattisson, T. CaMn ${ }_{0.875} \mathrm{Ti}_{0.125} \mathrm{O}_{3}$ as Oxygen Carrier for Chemical-Looping Combustion with Oxygen Uncoupling (CLOU)-Experiments in a Continuously Operating Fluidized-Bed Reactor System. International Journal of Greenhouse Gas Control, 5 (2011), 356-66.

(15) Azimi,G.; Leion, H.; Mattisson, T.; Lyngfelt, A. Chemical-Looping with Oxygen Uncoupling Using Combined Mn-Fe Oxides, Testing in Batch Fluidized Bed. 10th International Conference on Greenhouse Gas Control Technologies, 4 (2011), 370-77.

(16) Azimi,G.; Leion, H.; Mattisson, T,; Lyngfelt, A. $\left(\mathrm{Mn}_{\mathrm{z}} \mathrm{Fe}_{1-\mathrm{Z}}\right)_{\mathrm{Y}} \mathrm{O}_{\mathrm{x}}$ Combined Oxides as Oxygen Carrier for Chemical-Looping with Oxygen Uncoupling (Clou). AIChE Journal (2012).

(17) Cao, Y.; Casenas, B.; Pan, W, P. Investigation of chemical looping combustion by solid fuels. 2.

Redox reaction kinetics and product characterization with coal, biomass, and solid waste as solid fuels and $\mathrm{CuO}$ as an oxygen carrier. Energy \& Fuels, 2006. 20(5): p. 1845-1854.

(18) Forero, C, R.; Gayan, P.; Garcia-Labiano, F.; de Diego, L, F.; Abad, A.; Adanez, J. High temperature behaviour of a $\mathrm{CuOh} /$ gamma $\mathrm{Al} 2 \mathrm{O} 3$ oxygen carrier for chemical-looping combustion. International Journal of Greenhouse Gas Control, 2011. 5(4): p. 659-667.

(19) de Diego, L, F.; Garcia-Labiano, F.; Adanez, J.; Gayan, P.; Abad, A.; Corbella, B, M.; Palacios, J, M. Development of Cu-based oxygen carriers for chemical-looping combustion. Fuel, 2004. 83(13): p. 1749-1757.

(20) Cao, Y.; Chen, Z, X.; Riley, J, T.; Pan, W, P. Reduction of solid oxygen carrier (CUO) by solid fuel (COAL) in chemical looping combustion. Abstracts of Papers of the American Chemical Society, 2005. 229: p. U857-U857.

(21) Eyring, E, M.; Liao, P, H.; Wang, H, P. Chemical structure of $\mathrm{CuO}-\mathrm{NiO} /$ chabazite oxygen carrier in chemical-looping combustion. Abstracts of Papers of the American Chemical Society, 2009. 237.

(22) Monazam, E, R.; Siriwardane, R.; Breault, R, W.; Tian, H, J.; Shadle, L, J.; Richards, G.; Carpenter, $\mathrm{S}$. Kinetics of the Reduction of $\mathrm{CuO}$ /Bentonite by Methane $\left(\mathrm{CH}_{4}\right)$ during Chemical Looping Combustion. Energy \& Fuels, 2012. 26(5): p. 2779-2785.

(23) Zhao, H,B.; Mei, D,F.; Ma, Z,J.; Yang, W,J.; Fang, Y,F.; Zheng, C,G. Oxygen Release Kinetics and Mechanism Study on Cu-, Co-,Mn-Based Oxygen Carrier . FUEL CHEMISTRY AND TECHNOLOGY, 41 (2013), 235-42.

(24) Azad, A,M.; Hedayati, A.; Rydén, M.; Leion, H.; Mattisson, T. Examining the $\mathrm{Cu}-\mathrm{Mn}-\mathrm{O}$ Spinel System as an Oxygen Carrier in Chemical Looping Combustion. Energy Technology, 2013: p. 59-69.

(25) Rydén, M.; Leion, H.; Mattisson, T.; Lyngfelt, A. Combined Oxides as Oxygen Carrier Material for Chemical-Looping Combustion with Oxygen Uncoupling. 2nd International Conference on Chemical Looping, Darmstadt, Germany, September 2012 (2012).

(26) Stuer, M.; Zhao, Z.; Bowen, P. Freeze granulation: Powder processing for transparent alumina applications. Journal of the European Ceramic Society. 2012;32:2899-908. 
(27) Kunii, D.; Levenspiel, O. Fluidization Engineering. 2nd edn, Butterworth-Heinemann Series in Chemical Engineering (Boston: Butterworth-Heinemann, 1991), pp. xxvii, 491 p.

(28) Cocco, R.; Arrington, Y.; Hays, R.; Findlay, J.; Karri, S,B,R.; Knowlton, T,M. Jet cup attrition testing. Powder Technol. 2010 Jun 28;200(3):224-33.

(29) Rydén, M.; Leion, H.; Mattisson, T.; Lyngfelt, A. Combined Oxides as Oxygen Carrier Material for Chemical-Looping Combustion with Oxygen Uncoupling. Applied Energy (2013). 